\title{
Possível diálogo
}

\section{Reflexões sobre uma odisseia por vir - um diálogo filosófico}

\section{Patrick Pessoa (UFF)}

Resumo: O nosso texto apresenta um possível diálogo entre $\mathrm{P}$, um dramaturgo empenhado na elaboração de uma versão teatral da Odisseia, de Homero, e JM, uma filósofa que escreveu alguns estudos importantes sobre a dialética do esclarecimento em Homero. Eles investigam juntos como seria possível traduzir a Odisseia para a linguagem do teatro contemporâneo sem sacrificar o poder embutido em sua distância histórica. Ao fim do diálogo, P lê para JM o argumento de sua odisseia por vir.

Palavras-chave: Benjamin, Brecht, Adorno, Homero

Para Jeanne Marie Gagnebin, que me ensinou, e continua me ensinando, a beleza da dedicação e das dedicatórias

$\mathrm{P}$ - Que bom que você pôde vir conhecer minha casa nova, mesmo depois de passar o dia inteiro assistindo àquelas intermináveis comunicações.

JM - Ah, mas eu adoro Santa Teresa. Essa é talvez minha única afinidade com os franceses... E esses encontros pessoais fora do ambiente acadêmico são quase sempre a melhor parte dos congressos de filosofia. É mais fácil ser inteligente quando a gente não precisa parecer inteligente. Tenho uma certa dificuldade em confiar em gente que nunca se dá o direito de falar abobrinha.

P - E se a gente rebatizasse aquelas páginas da Dialética do esclarecimento sobre os perigos do enrijecimento do sujeito esclarecido?

JM - Rebatizasse como?

$\mathrm{P}$ - O que você acha de "Beiträge zu einer Zucchiniphilosophie" ["Contribuições para uma filosofia da abobrinha"]?

JM - Esses meninos do Rio... Apesar de tudo, você sabe, sou séria pra chuchu.

P - Claro que sei! Aliás, te convidei para vir aqui hoje por um motivo sério. Pelo menos para mim. É que estou escrevendo uma versão da Odisseia para o teatro e ando mergulhado num mar de dúvidas. Mergulhado não. Naufragado.

JM - Como Ulisses? Talvez seja um bom começo...

P - É, como Ulisses, mas sem Atena para me ajudar. A não ser que você aceite ser a minha Atena...

$\mathrm{JM}$ - Mais tu exagères... 
$\mathrm{P}$ - Que nada! Tenho lido e relido os teus textos sobre a Odisseia e acho que, se existe alguém que pode me ajudar, esse alguém é você! Sabia que agora, na maioria das peças de teatro, existe a figura do "consultor teórico"?

JM - Que horror!

P - Pois é. Mas o meu problema agora é esse: incorporar a teoria e ver se consigo encontrar um caminho de volta pra casa. Para te ser sincero, sempre achei que a minha Ítaca era a ficção, e que a filosofia era só, talvez, aquele belo navio dos feácios. Com dezoito anos, eu tinha a ilusão de que a viagem ia ser rápida e que eu ia chegar em casa cheio de ricos presentes. Agora, vinte anos depois, a viagem já começa a me parecer longa demais e os tais ricos presentes se tornaram um lastro excessivo que antes dificulta do que facilita a navegação.

JM - Isso que você está dizendo me lembra muito aquele lindo poema do Kaváfis, você conhece? O final diz assim:

Todo tempo em teu íntimo Ítaca estará presente.

Tua sina te assina esse destino,

mas não busques apressar tua viagem.

É bom que ela tenha uma crônica longa duradoura, que aportes velho, finalmente, à ilha,

rico do muito que ganhares no decurso do caminho, sem esperares de Ítaca riquezas.

Ítaca te deu essa beleza de viagem.

Sem ela não a terias empreendido.

Nada mais precisa dar-te.

Se te parece pobre, Ítaca não te iludiu.

Agora tão sábio, tão plenamente vivido,

bem compreenderás o sentido das Ítacas.

P - Você lembra desse poema de cor? E ainda mais na tradução do Haroldo?! Eu não estava exagerando quando imaginei que você poderia ser minha Atena... Obrigado pelo consolo. Só que, por mais paciente que eu tenha sido até agora, me angustia demais a ideia de aportar já velho em Ítaca. E se, por algum motivo, eu não viver até lá? Afinal, já tenho a mesma idade do Ulisses que finalmente conseguiu regressar...

JM - Fique tranquilo. Se neste nosso tempo dos aviões e da internet, se os navios demoram mais a chegar a seus destinos, é apenas porque as vidas humanas duram também mais... Ia dizer "ora e labora", se dissesse coisas do tipo. Mas hoje, só hoje, se você quer mesmo que eu te guie, vamos começar do começo. Talvez algumas perguntas simples possam ajudar. A primeira de todas: se é mesmo verdade que "só o desejo ensina", como propõe aquela tua subversiva tradução do páthei máthos do Ésquilo, que desejo te moveu até essa ideia de encenar a Odisseia?

$\mathrm{P}$ - Na verdade, tudo começou com um convite de um diretor amigo meu. Sendo belga, como ele diz, radicado aqui no Rio há mais de vinte anos, ficou obcecado com a ideia de levar para o teatro toda aquela problemática do Ulisses como estrangeiro, das diferentes compreensões de hospitalidade, do medo de que, ao fim e ao cabo, a volta pra casa acabe por se mostrar impossível.

JM - Interessante... Como estrangeira no Brasil, acho que entendo perfeitamente o ponto de partida do teu amigo. Taí uma peça que eu gostaria de ver.

Cadernos Benjaminianos, Número especial, Belo Horizonte, 2013, página 26-40 
P - Ele fez inclusive umas oficinas com atores de Brasília e de Porto Alegre construídas em torno daquelas perguntas que são repetidas o tempo todo no texto do Homero. Depois posso te mandar os vídeos por email.

JM - De que perguntas você está falando?

P - Peraí. Deixa eu pegar a tradução que estou usando. As passagens estão marcadas. Por exemplo, tem esta aqui: "Inquirir estrangeiros sobre quem são eles, quando o festim os satisfez, não nos denigre. Sois quem? De onde partiu a trajetória úmida? O que vos traz? Negócio ou foi o prazer das vagas, piratas que erram pelo mar, a própria vida em risco na aflição levada aos estrangeiros?"

JM - A tradução é um pouco estranha, mas claro que me lembro dela. Essa passagem está em que canto?

P - No canto III, quando o Telêmaco chega a Pilos para encontrar o velho Nestor.

JM - É verdade. De fato, essas perguntas atravessam A Odisseia inteira. Aparecem sempre que um estrangeiro chega a uma terra desconhecida. Você pode ler para mim outros exemplos? É sempre um prazer ouvir recitarem Homero.

P - Eu também adoro. Bons tempos da recepção oral. Aqui há outra passagem semelhante. Polifemo, ao se deparar com Ulisses e os seus acompanhantes, pergunta: "Alienígenas, sois quem? De onde partistes pela senda líquida? Que afazer vos moveu? Singrais o mar tais quais piratas divagantes que, arriscando a própria ânima, atemorizam gente nunca vista?"

JM - Cuidado com as falsas semelhanças. As perguntas do Nestor têm um sentido muito diferente das do Polifemo. O Nestor só interroga os estrangeiros depois de acolhê-los. Como ele diz, um anfitrião seria "denegrido" se perguntasse pela identidade dos recémchegados antes de acolhê-los. Já o Polifemo não reconhece essa regra fundamental da hospitalidade.

$\mathrm{P}$ - Claro, a diferença é gritante. Desculpe se estou lendo agora meio ao acaso...

JM - É uma pena que a nossa civilização seja mais de Polifemos que de Nestores. Mas o que exatamente o teu amigo belga pensou em fazer com essas perguntas?

$\mathrm{P}$ - Nos vídeos que ele fez, os atores tentam respondê-las, falando diretamente para a câmera. Tentam simplesmente dizer quem são, de onde vieram, onde teria começado a viagem deles.

JM - Pela senda líquida ou pela trajetória úmida?

P - Concordo contigo. A tradução do Trajano, apesar de ser ótima para estudar, é intransponível para a cena. Por isso é que fiquei com vontade de escrever um texto original. Um texto que caiba na boca dos atores, como tentei fazer com a Oréstia.

JM - Sim, mas então qual seria a diferença entre os dois projetos? Você já deve estar bem treinado nessas adaptações.

Cadernos Benjaminianos, Número especial, Belo Horizonte, 2013, página 26-40 
P - Na verdade não. Continuo me sentindo um alienígena no teatro, como diria o Trajano. Por isso, como o Michel Piccoli no filme do Godard, resolvi assumir o desafio de reescrever o original do Homero, sem necessariamente usar suas palavras.

JM - Se bem me lembro, no filme do Godard, o Michel Piccoli só é chamado para "reescrever Homero" porque o Jack Palance, que era o produtor do filme dentro do filme, achava que o Fritz Lang não estava fazendo um filme suficientemente comercial. A princípio, ele tinha contratado o Lang para filmar a Odisseia porque achava que só um alemão podia fazer aquilo. Mas, ao ver os primeiros rushes, logo se arrepende. Então ele paga uma fortuna ao Piccoli para escrever uma nova Odisseia com mais cenas de sexo, com alguma coisa que pudesse vender mais ingressos, gerar mais identificação com a plateia. Espero que, quando você fala em reescrever Homero, não esteja pensando em algo parecido. É preciso ter muito cuidado com essas "atualizações".

P - "Quando ouço falar em cultura, eu saco o meu talão de cheques."

JM - "Eu sei exatamente como os deuses se sentem."

P - Você se lembra disso, querida Atena?! É, as melhores falas do filme ficaram para o Jack Palance. Acredite se quiser!

JM - Acho que você não deve esquecer aquilo que o Benjamin diz no texto sobre as afinidades eletivas: "A distância histórica aumenta o poder das obras."

P - Claro, nada de atualizações, você tem toda razão. Essa é inclusive a posição do Fritz Lang no filme. Ele diz que acha estúpido querer transformar o Ulisses num neurótico moderno. Rechaça a tese do produtor de que a Odisseia foi a desculpa do Ulisses para não voltar para casa, já que estava cansado da Penélope, insatisfeito com o casamento...

JM - Que saudade desse filme. Quando voltar para Campinas, vou rever imediatamente Le mépris.

P - Para mim, é um dos melhores filmes do Godard. Se não for o melhor. Apesar de o Godard pessoalmente desprezá-lo. Li uma entrevista dele em que ele diz que $O$ desprezo é o seu filme mais convencional.

JM - Sério? Mas qual é o problema da ideia do teu amigo diretor? Os vídeos não ficaram bons?

$\mathrm{P}$ - Para mim, é o tal problema da atualização. Colocar atores jovens para responder às perguntas que são endereçadas ao Ulisses e ao Telêmaco, por mais interessantes que sejam as respostas, leva a um endeusamento da biografia dos atores que é um dos pecados capitais do teatro contemporâneo. A história de vida dos atores não me interessa. Claro que essas histórias podem ser interessantes. Mas jamais vão ter o alcance das histórias de um Ulisses, de um Hamlet, enfim, de um personagem de ficção.

JM - A princípio não. Mas tudo depende justamente do trabalho de ficção, da elaboração estética. Cabe a você, como dramaturgo, converter as sensações e as lembranças que eles evocarem em linguagem, transfigurar a sensação em sentido.

$\mathrm{P}-\mathrm{E}$, de início, quando aceitei o convite, era isso que eu pretendia fazer. Mas, depois de conhecer pessoalmente os atores escalados para a peça, que são talvez excessivamente

Cadernos Benjaminianos, Número especial, Belo Horizonte, 2013, página 26-40 
jovens, fiquei com medo de que, tendo a chance de recontar as próprias vidas como odisseias, eles não conseguissem sair de si para instaurar um outro mundo na cena. A tendência seria que a peça acabasse autorreferente, engraçadinha, "atual" no pior sentido do termo. Não sei se você tem ido muito ao teatro...

JM - Na verdade, só muito raramente...

$\mathrm{P}$ - Então talvez você não tenha tido tantas vezes quanto eu a dolorosa experiência de ver que em geral os atores jovens, esses que querem fazer um "teatro contemporâneo", vão se tornando progressivamente incapazes de sair de si, de viver e de dar a ver outras vidas, de realmente encarnarem um personagem...

JM - Desculpe interromper, mas acho muito estranho ouvir isso de um brechtiano. Quer dizer que você está defendendo a empatia entre ator e personagem?!

$\mathrm{P}$ - O mundo do teatro talvez dê mais voltas que o teatro do mundo, não sei. Só sei que, no Rio de Janeiro, nos últimos vinte anos, o imperativo épico de que o ator guarde distância do personagem, de que o apresente e comente suas ações sem se deixar confundir com ele, acabou gerando uma insuportável cultura do narcisismo. Matam-se os autores e seus textos em nome de uma postura ostensivamente irônica, espertinha, que privilegia exclusivamente os atores e seus jogos de cena em detrimento da reflexão. $\mathrm{O}$ que Brecht imaginava como sendo um procedimento politicamente revolucionário, desestetizante, acabou se tornando o suprassumo da estetização. Hoje, as tão necessárias interrupções, que obrigam atores e espectadores a saírem do lugar, aquela dupla desapropriação do sujeito da interpretação a que alude o Ricoeur com o conceito de "refiguração", acabou se convertendo no culto acrítico de pseudo-interrupções.

JM - Se é verdadeiro esse teu diagnóstico, se o distanciamento entre ator e personagem não funciona como uma verdadeira interrupção do drama, mas como um reforço da identificação em outro nível, o da esperteza pós-moderna, então de fato alguma coisa está errada. Mas o simples retorno a um teatro pré-brechtiano também não é mais possível. $\mathrm{O}$ que você propõe no lugar dessas pseudo-interrupções, dessa falsa auto-reflexividade?

P - Essa é, para mim, a questão. Tenho pensado muito em como conciliar a necessidade de interrupções e a minha vontade de não deixar a cargo dos atores e seus jogos de cena o ônus de promover essas interrupções.

JM - O Brecht, você sabe, usava projeções no fundo da cena, com informações que punham em questão a posição dos personagens, obrigando a um distanciamento dos espectadores com relação a seus "dramas individuais" mesmo quando não se produzia a quebra da empatia entre ator e personagem.

$\mathrm{P}$ - Você certamente tem ido mesmo pouco ao teatro... Nem me fale em usar projeções! O que era revolucionário no tempo do Brecht se tornou o clichê do clichê! Quando ouço falar em projeções, tenho vontade de sacar o meu revólver!

JM - Estou vendo que toquei num ponto sensível, com todo o respeito. Mas, se para você, nem o improviso, nem o jogo dos atores, nem as projeções são permitidas, a única coisa que restaria seria o texto.

P - Não, não só o texto. Tem os figurinos - como aqueles que o Brecht usou na montagem do Mann ist Mann com o Peter Lorre -, tem a luz, os cenários e tem sobretudo

Cadernos Benjaminianos, Número especial, Belo Horizonte, 2013, página 26-40 
a música, que pode ser usada, como aliás o Godard sempre usou muito bem no cinema, para interromper a ação, e não simplesmente para ilustrá-la.

JM - Curioso isso. Quando você pensa no Brecht, lembra imediatamente do Godard...

$\mathrm{P}$ - Óbvio! Godard é o Brecht do cinema! E, aliás, tinha plena consciência disso. Lembra daquela cena da Chinoise? O Léaud escreve num quadro negro os nomes de todas as grandes personalidades da história: artistas, políticos e filósofos. Depois, vai apagando um por um. E o último nome que fica no quadro é o do bom e velho BB.

\section{$\mathrm{JM}$ - Brigitte Bardot?}

$\mathrm{P}$ - A caipirinha deve estar te subindo à cabeça... Aliás, quer mais uma?

JM - Com todo prazer. Esta aqui está ótima. Mas agora falando sério: entendo que o jogo dos atores, hoje em dia, possa estar levando a um certo narcisismo, a esse insuportável culto pós-moderno da ironia, que hoje se transformou em uma insígnia de classe. Também não gosto nem um pouco desse "fetiche da ironia". Mas, quando você menciona todos os outros elementos cênicos, além do texto e dos atores, como potenciais fontes de interrupção, não acaba querendo usurpar a função do diretor? O que o teu amigo belga acha disso?

$\mathrm{P}$ - Na verdade, ainda não conversei com ele. O diabólico de se entregar a um projeto teatral como estou me entregando a esta Odisseia é justamente esse: na elaboração do texto, querer dar mais indicações cênicas do que aquelas que cabem a um dramaturgo. Talvez eu devesse logo assumir essa minha vontade de dirigir... Mas uma coisa aprendi nas minhas experiências teatrais anteriores: que a beleza do teatro é o seu caráter colaborativo. As funções acabam se misturando e isso, apesar das brigas, é ótimo para o processo e, claro, para o produto final. Por isso, inclusive, me sinto muito mais atraído pelo teatro do que pela literatura. E mesmo do que pela filosofia, onde o trabalho colaborativo é quase impossível.

JM - Não concordo totalmente com você. Já participei de congressos e, sobretudo de defesas de tese, em que se instaurava um verdadeiro coletivo. Para não falar nas aulas.

$\mathrm{P}$ - Deve ser então por isso que, para o meu espanto, você aceita tantos convites. No seu lugar, acho que eu não teria a mesma energia.

JM - Tenho consciência de que essa experiência de um verdadeiro trabalho coletivo em filosofia é rara, mas, quando acontece, redime todas as outras em que não chega a acontecer. Acho politicamente fundamental aceitar tantos convites, contribuir para a construção de uma universidade mais interessante, mais viva. Mas acho que estamos nos desviando do assunto.

P - Não foi o teu amigo BB, quer dizer, WB que disse que método é desvio?

JM - Como não? Mas, se você quer mesmo que eu seja a tua Atena, deixa eu te dizer que, ao querer usurpar todas essas funções que cabem mais naturalmente à direção, você tende a se afastar da tua Ítaca. Se, a princípio, você será o dramaturgo dessa encenação da Odisseia, acho fundamental você pensar em um modo de, unicamente através do texto, sem precisar interferir em cenário, figurino, etc, produzir essas interrupções que ambos achamos tão necessárias para que a tua adaptação de Homero não se transforme em um

Cadernos Benjaminianos, Número especial, Belo Horizonte, 2013, página 26-40 
crime como foi aquele filme Tróia. Ou, tratando de um assunto ainda mais delicado, $A$ lista de Schindler.

P - Você tem toda razão. Vamos então nos concentrar na discussão do texto dessa possível Odisseia por vir. Na realidade, eu tenho uma ideia, tive uma visão bastante clara da minha Odisseia, e queria saber o que você acha.

JM - Sou toda ouvidos.

$\mathrm{P}$ - Desculpe, fico com um pouco de vergonha. Talvez porque, como o Kaspar Hauser do filme do Herzog, tenham me programado a só contar uma história cujo final eu conheça...

JM - Sim, mas você se lembra que, no leito de morte, o Kaspar se permitiu contar o seu sonho mesmo sem saber o final? O sonho era mais ou menos assim: "Vi uma enorme caravana de beduínos no meio do deserto. E eles eram guiados por um cego. Depois de muito andar, eles pararam. Havia uma montanha muito alta diante deles. O cego ajoelhou-se, colocou a areia do deserto na boca, como se fosse comida, ruminou-a e, finalmente, disse: 'Essas montanhas altas demais são uma ilusão. Sigamos em frente.' A caravana seguiu. A montanha era de fato uma ilusão e eles chegaram à cidade mais próxima, onde a história continua. Mas aí eu não sei mais o que acontece."

P - Que bonito isso! Não me lembrava. Parece um pouco uma frase do ímã de geladeira que tem aqui em casa, atribuída ao Sêneca. Está em francês porque comprei em Paris. O Sêneca diz o seguinte - me desculpe pelo sotaque: "Ce n'est pas parce que les choses sont difficiles que nous n'osons pas, c'est parce que nous n'osons pas qu'elles sont difficiles."

JM - Você me pedindo desculpas pelo sotaque?! Não confio em quem consegue perder totalmente o sotaque... Pobre do Sêneca, transformado em ímã de geladeira! Mas alto lá: até os desvios têm limite! Me conta logo: como é que vai ser a tua Odisseia?

P - Na verdade, não será exatamente uma Odisseia. Será mais uma Telemaquia.

JM - Mas a Telemaquia perfaz só os primeiros quatro cantos do poema!

$\mathrm{P}$ - Sim, mas são justo esses quatro primeiros cantos que me movem. Tenho mais afinidade com o filho do que com o pai.

\section{JM - Como o Fénelon... Conhece Les aventures de Télémaque?}

P - Li há pouco tempo. Mas achei chatíssimo, de um moralismo insuportável. Como devia ser chato ser preceptor dos jovens reis... Se não me engano, o texto foi escrito para preparar um dos netos do Luís XIV para, algum dia, assumir a coroa. Não sei se ele chegou ao trono, mas o livro, em todo caso, é completamente orientado para uma educação principesca. Não é à toa que hoje soe tão datado.

JM - É verdade. Mas o pecado capital do Fénelon não é esse. Ele é profundamente antihomérico ao condenar peremptoriamente a ficção. Há diversas passagens em que o Telêmaco dele, em vez de construir uma narrativa ficcional para escapar a um perigo, como o Ulisses de Homero, é forçado por seu mentor, na verdade uma versão disfarçada e cristianizada de Atena, a dizer a "verdade objetiva".

Cadernos Benjaminianos, Número especial, Belo Horizonte, 2013, página 26-40 
P - Pois é, às vezes eu torcia para ele morrer por conta dessa recusa da ficção.

JM - Em todo caso, me lembrei do Fénelon porque ele transforma os quatro primeiros cantos da Odisseia em um romance pedagógico bem longo...

$\mathrm{P}$ - Longo até demais!

JM - ... que se sustenta numa contradição performativa interessante. Com o propósito de condenar a ficção, ele acabou escrevendo uma obra de ficção que, durante uns bons dois séculos, foi um dos grandes best-sellers do Ocidente. Mesmo que a tua pegada não seja essa, acho um bom exemplo de um desdobramento possível da Telemaquia...

P - Consegui tirar muito menos da minha leitura do Fénelon do que esperava, infelizmente. Mas, pensando agora no que você está me dizendo, me lembrei de que, no início do nosso processo de estudo da tradução do Trajano, a ideia era justamente privilegiar esses momentos de narrativa dentro da narrativa, de ficção ou mesmo autoficção escancarada, que perpassam a Odisseia inteira. Esse era sem dúvida um dos principais desejos do diretor com quem estou trabalhando.

JM - Claro. Uma versão da Odisseia que não incorpore a riqueza desse Ulisses aedo, que não seja em alguma medida um elogio da ficção e um pensamento sobre o ficcionar, sobre a ficção da verdade e a verdade da ficção, desperdiça um dos aspectos mais interessantes e, eu diria mesmo, mais contemporâneos do poema.

P - Concordo totalmente. A auto-reflexividade do romance moderno já está toda antecipada na Odisseia. E, curiosamente, não seria assim tão complicado traduzir essa auto-reflexividade para o teatro contemporâneo. Bastaria utilizar um procedimento que a Cia. dos Atores, aqui do Rio, usou de uma maneira muito instigante nas suas montagens do Hamlet e da Gaivota. Além de encenarem apenas fragmentos dos respectivos originais e de fazerem os atores se revezarem na incorporação dos personagens principais...

JM - A meu ver uma das heranças mais interessantes do teatro didático brechtiano...

P - ... nessas montagens da Cia. dos Atores a própria distância histórica era problematizada em cena. A distância histórica que, apesar de potencialmente aumentar o poder das obras, como você disse há pouco, torna difícil a criação de laços com o público. Assim, os atores, ao dizerem um trecho célebre do Shakespeare, por exemplo, sempre faziam questão de ostentar a dificuldade de dizer aquilo.

$\mathrm{JM}$ - Esse procedimento me parece bem interessante.

$\mathrm{P}$ - Com certeza. Funcionou muito bem nessas peças, que são verdadeiros clássicos do contemporâneo. O problema é que, hoje, o que foi uma estratégia cênica potente, uma apropriação original dos clássicos, acabou se convertendo em uma fórmula desgastada. Que, a meu ver, tem um grave inconveniente: dá espaço demais para que os atores improvisem e tentem encurtar a distância histórica com paralelos, quase sempre engraçadinhos, entre a estranheza do original e a banalidade do atual.

JM - Procedimento semelhante ao da pop art?

P - Nunca tinha pensado sob esse viés, mas acho que sim. Quando uma atriz da Gaivota, por exemplo, começa a enumerar uma série de remédios tarja preta de hoje em dia para

Cadernos Benjaminianos, Número especial, Belo Horizonte, 2013, página 26-40 
situar contemporaneamente o caráter instável e histriônico da Arkadina, aquilo funciona muito bem com o público. As pessoas gargalham. Mas alguma coisa de essencial se perde. Metafisicamente, eu diria: a dor. Além disso, o equilíbrio do todo tende a ser abalado pelo virtuosismo de alguns atores que se sentem confortáveis demais com esses cacos, a ponto de tenderem a esticá-los mais do que seria razoável. E, não raro, suportável!

JM - Baixou o Aristóteles em você?! Equilíbrio do todo versus virtuosismo dos atores é uma daquelas dicotomias aristotélicas que o fazem condenar as tragédias excessivamente episódicas. Ele chega inclusive a repreender os tragediógrafos que alongam demais certos episódios só para deixarem um ator se exibir. Mas, depois de Brecht, será que ainda faz sentido condenar essa infiltração de elementos épicos no drama? Será que ainda faz sentido falar em equilíbrio e harmonia do todo?

$\mathrm{P}$ - Sei que a minha posição parece um pouco reacionária, classicista, anacrônica, careta, burra, etc. E talvez de fato seja. Mas ela não está fundada em princípios. Como diria o Marx, sou um homem de princípios. Se a senhora não gostar deste, tenho outros...

JM - O Groucho, você quer dizer...

P - Minha posição nasce tão somente do hábito de ir ao teatro e de ver como o narcisismo dos atores destrói algumas peças. Aristóteles, no tempo dele, condenava os dramaturgos que lisonjeavam os atores alongando demais suas falas. Imagina o que ele diria dos atores de hoje em dia que simplesmente roubam o lugar do dramaturgo e inventam os seus textos. Quando ouço falar em cacos, eu saco o meu revólver!

JM - Mon Dieu, você está sacando esse revólver a torto e a direito! Espero que a sua pontaria esteja boa... Em todo caso, você só está repetindo o que disse mais cedo: não quer deixar na mão dos atores o ônus das interrupções, não quer que os momentos de auto-reflexividade da peça dependam exclusivamente de achados performáticos. Isso eu já entendi. Não precisa repetir. Fico me perguntando o que esses pobres desses atores te fizeram...

$\mathrm{P}-\mathrm{Nada}$ ! Eu amo os atores.

JM - Sei. Com um amigo assim, quem precisa de inimigos?

$\mathrm{P}$ - Sério, eu amo os atores. Desde que digam direitinho o meu texto...

JM - Mas então me explique como, mantendo os atores com uma focinheira e sem apelar para uma usurpação das funções do diretor - seria irônico se você fizesse com o diretor o que teme que os atores façam com o teu texto! Como você pretende trabalhar as interrupções exclusivamente no nível do texto? Me conta logo a tua ideia. Está ficando tarde e não sei mais quantas caipirinhas aguento.

$\mathrm{P}$ - A chave, naturalmente, vai estar no processo de montagem dos fragmentos do texto. Num jogo delicado entre o passado e o presente que nem anule a distância histórica nem deixe com que a encenação acabe ficando empostada e sucumba ao peso da tradição. Sob esse aspecto, a ideia inicial do meu amigo belga era bem interessante. $\mathrm{O}$ caminho de volta para casa do Ulisses seria o caminho de volta para o texto de Homero.

Cadernos Benjaminianos, Número especial, Belo Horizonte, 2013, página 26-40 
$\mathrm{JM}$ - Quer dizer que você integraria naquelas respostas dos próprios atores às perguntas repetidas aos estrangeiros no original do Homero que você leu para mim há pouco, essa nostalgia de bons textos?

$\mathrm{P}$ - Exatamente. Essa é sem dúvida uma queixa comum de quem faz teatro hoje em dia. Faltam bons autores, de modo que, mesmo que a princípio permitíssemos que as biografias dos atores se infiltrassem no texto do espetáculo, elas logo poderiam ser reconduzidas ao fio condutor original: o texto de Homero. As respostas deles aludiriam à inexistência de rotas seguras para sua existência como atores. Ora, rotas seguras em teatro são bons textos. Haveria aí uma nostalgia de casa, da "identidade original" do teatro, do texto como uma Ítaca. Essa nostalgia entraria em contradição com todos os prazeres momentâneos do esquecimento (lotófagos), da animalidade (Circe), da música (sereias). Supondo que todos esses elementos não logocêntricos podem ser pensados sob a rubrica do "improviso", esquematicamente falando: a dialética da nossa montagem seria entre o texto e o improviso, o clássico e o contemporâneo, a alma e o corpo.

JM - Interessante esse movimento de uma volta para casa como uma volta para o texto.

P - Assim, o contemporâneo não estaria mais na avacalhação dos clássicos, que acho lamentável, mas numa fragmentação e numa remontagem previamente decididas pela dramaturgia e, talvez, num modo novo de elocução que partiria da própria problematização do ideal ingênuo de fidelidade. O Roberto Alvim, da Cia. Club Noir, de São Paulo, conseguiu um resultado muito feliz nessa direção quando encenou as sete tragédias do Ésquilo. Acho didaticamente fundamental que os atores jovens entendam que sua justa recusa de um textocentrismo empoeirado não pode ser confundida com o repúdio indiscriminado a qualquer texto poético mais elaborado. Aprendendo a separar o joio do trigo, nossos atores que se revezariam no papel de Ulisses finalmente conquistariam a possibilidade de recitar Homero dignamente.

JM - Esse caminho, que eu ousaria chamar de bastante contemporâneo, me parece de fato muito rico. Só não entendi como essa ideia se coaduna com o que você disse antes. Para encenar a auto-reflexividade da Odisseia, calcada na figura do Ulisses como aedo, o Ulisses seria o personagem mais presente em cena. Como é que daí poderia sair uma versão da Odisseia centrada na Telemaquia?

P - De fato, acho que não há conciliação possível. Essa Odisseia que tematizaria explicitamente toda a problemática da narração dentro da narração, que seria ostensivamente auto-reflexiva, que construiria uma analogia entre o Ulisses que tem de atuar diante da corte dos feácios e o ator contemporâneo que tem de atuar diante do seu público, essa Odisseia, que é a Odisseia vislumbrada pelo meu amigo belga, teria mesmo de se concentrar na figura de Ulisses. Nela, Telêmaco seria um personagem secundário...

JM - Então quer dizer que a Odisseia que você imaginou é ainda uma outra odisseia?

P - É. Uma odisseia outra. Quando ouço falar em metalinguagem, eu saco o meu revólver! Por isso, a minha proposta seria a de não transformar a auto-reflexividade em tema, jamais aludindo a ela diretamente. Gostaria que, como a ironia formal que o Benjamin descreve no livro sobre os românticos, ela aparecesse na própria tessitura do espetáculo.

JM - Do texto, você quer dizer?

Cadernos Benjaminianos, Número especial, Belo Horizonte, 2013, página 26-40 
P - Que seja, do texto. Nesta odisseia outra, a ação não se passaria nem na Grécia arcaica nem no mundo do teatro. Ela se passaria no Brasil de hoje em dia, o Brasil em que se instituiu uma "Comissão da Verdade" nos moldes da que foi criada na África do Sul. Os personagens principais, Telêmaco e Penélope, seriam o filho e a mulher de Ulisses, um desaparecido político na ditadura militar. Ulisses talvez nem fosse o seu nome verdadeiro, mas o seu nome de guerra.

JM - Ulisses, realmente, parece hoje mais um nome de guerra do que qualquer outra coisa.

P - E a busca do Telêmaco, na minha peça, seria a busca do pai desaparecido, desse morto sem sepultura. A minha odisseia, portanto, seria orientada pelo imperativo ético de lembrar os mortos, de ajudar a romper esse silêncio em torno da tortura no Brasil que dá margem à contínua repetição do horror.

JM - Agora entendo por que você me convidou especialmente para essa conversa sobre a Odisseia. Essa ideia de apresentar o Ulisses como um desaparecido político tem tudo a ver com as minhas reflexões dos últimos anos.

P - Claro! Acho que, se não tivesse lido o Lembrar escrever esquecer, que é um dos livros da minha vida, jamais teria chegado a essa ideia. Ela de algum modo brota da articulação entre a tua leitura da figura de Ulisses na Dialética do esclarecimento e as tuas reflexões sobre o imperativo ético de trabalhar para que nada de semelhante a Auschwitz se repita. Minha peça, nesse sentido, vai se alimentar da tarefa paradoxal a que você tantas vezes alude no teu livro: a tarefa de transmitir o inenarrável sem convertê-lo em uma mercadoria que faz sucesso e assim acaba por legitimar a própria cultura que engendrou o horror. De início, para além de todas aquelas questões estéticas que acabamos de discutir, minha ideia é escrever uma peça que possa colaborar naquele indispensável trabalho de luto que, ao elaborar a verdade do passado, torne possível também um presente mais verdadeiro.

JM - De fato, venho sentindo muito nojo da cobertura que a grande imprensa tem feito das manifestações no país, elogiando sempre que possível a Polícia Militar e as forças repressivas, as prisões abusivas, ajudando a perpetuar esse verdadeiro terrorismo de Estado em meio ao qual, desde a ditadura, vivemos. Nas favelas, você sabe, tortura e extermínio nunca deixaram de ser tristemente atuais. É curioso ver que só agora a classe média, que começa a sentir na pele essa violência imemorial, esteja começando a abrir os olhos.

P - Uma pequena parcela da classe média, infelizmente. Mas, sem dúvida, acho que houve sim uma mudança na nossa percepção da realidade social que ainda é difícil de mensurar. As grandes manifestações deste ano foram em todo caso fundamentais para o crescimento da minha indignação e o amadurecimento da minha ideia. Não está dando mais para seguir só estudando filosofia e publicando artigos acadêmicos que tão pouca gente vai ler. Acho que uma peça de teatro tem condições de ser uma intervenção, uma ação mais efetiva. Quero sinceramente passar da Schulphilosophie [filosofia acadêmica] para uma Weltphilosophie [filosofia do mundo]!

JM - Então acho que você está no bom caminho. O teatro sempre foi uma seara privilegiada para o debate político.

$\mathrm{P}$ - Nem sempre. Pelo menos no Rio, desde que me entendo por gente, o teatro tem sido lamentavelmente apolítico. Por isso é que tenho ficado tão revoltado com o caráter

Cadernos Benjaminianos, Número especial, Belo Horizonte, 2013, página 26-40 
eminentemente estetizante do teatro que fazemos aqui. Por isso é que quero tentar alguma coisa diferente.

JM - Acho que agora entendo melhor por que você falou tantas vezes em sacar o revólver. Outro dia, também pensei em sacar o meu. Li no jornal que, na saída de uma dessas reuniões de antigos torturadores no Clube Militar do Rio, os jornalistas cercaram um oficial e lhe perguntaram o que ele achava da revisão da lei da anistia e da questão da tortura, que foi recentemente proposta por entidades de defesa dos direitos humanos. Sabe o que ele respondeu? Que eles não deveriam ter torturado as pessoas, mas simplesmente matado, pois aí não haveria mais revisões desse tipo. Se fosse na Europa, ou mesmo na Argentina e no Chile, que viveram realidades bem mais próximas, um camarada desse teria sido colocado imediatamente na reserva. Se não na cadeia! E no Brasil não acontece nada.

$\mathrm{P}$ - É inaceitável isso. Toda a busca do meu indignado Telêmaco parte justamente dessa constatação. Sei que já está tarde, mas você ainda teria disposição para ouvir a minha leitura do argumento da peça que escrevi? É uma folha apenas.

JM - Claro. Agora é que a conversa está esquentando.

P - Telêmaco, 20 anos, adora literatura e quer ser escritor. Como o Treplev da Gaivota, ou o filho de Tudo sobre minha mãe, do Almodóvar, tende a escrever uns textos meio simbolistas, bem distantes de qualquer questão mais diretamente política. Sua relação com a mãe, Penélope, é muito forte. Tendo vivido sempre sozinho com ela, adquiriu o hábito de ler para ela os seus escritos. A peça começa com uma dessas leituras, em que Telêmaco se compara a Cristo abandonado pelo pai na cruz. Ele vê a clássica figura do crucificado como a de um filho eternamente à espera de um abraço. $\mathrm{O}$ abraço do pai que nunca vem, do pai desaparecido. Penélope, como logo iremos ficar sabendo, é uma sobrevivente dos porões da ditadura militar que não gosta de falar do passado. Seu lema é que caminhemos sempre para a frente, ainda que o fato de jamais ter encontrado um novo amor depois do desaparecimento de Ulisses a desminta. Ela olha com ternura a melancolia do filho, mas está decidida a não abanar as brasas do passado. Com a instauração da Comissão da Verdade, porém, Telêmaco acaba tendo acesso ao depoimento do filho de um outro desaparecido, que fala da dor de ter crescido sem pai, da necessidade de achar os restos mortais daqueles que foram barbaramente assassinados, não apenas para podermos homenageá-los, lembrar de sua luta, mas também para podermos lhes dar um túmulo e seguir com a vida. A identificação de Telêmaco com o relato desse filho, chamado Orestes, irá levá-lo, pela primeira vez, a colocar a mãe em questão, perguntar como ela pôde não ter ido em busca de Ulisses. E se ele não tiver morrido? Sem a evidência do cadáver, não é possível ter certeza. Penélope é então movida a falar pela incompreensão de Telêmaco diante da sua opção de "esquecer" o passado. Quando, com enorme dificuldade, ela começa a falar, a narrar os horrores que sofreu, a explicar que por isso não teve como seguir em busca de Ulisses, nasce no filho o desejo de vingança. Os pretendentes se tornam aqui os torturadores, e é deles que Telêmaco pretende se vingar. Mas, para efetivar essa vingança, ele precisa do apoio do pai. Precisa refazer seu caminho, compreendê-lo. Para isso, vai em busca dos rastros de Ulisses. A princípio, consegue chegar até Nestor e Menelau, que combateram com ele e, depois de anos na prisão, voltaram para casa. Com base em seus relatos, Telêmaco começa a montar esse quebra-cabeça chamado Ulisses. Descobrir os algozes do pai, na cabeça de Telêmaco, passa então a confundir-se com a descoberta e o desmascaramento também dos torturadores de Penélope. A peça ganha ares de investigação detetivesca que são os ares da própria Telemaquia - e a tensão aumenta à medida que, sabendo mais detalhes sobre a história da tortura no Brasil, Telêmaco é tomado pelo desejo de matar um torturador específico. O clímax da peça é a cena em que Telêmaco, finalmente, fica

Cadernos Benjaminianos, Número especial, Belo Horizonte, 2013, página 26-40 
cara a cara com o torturador da mãe (indiscernível, no mundo da peça, do provável assassino do pai).

$\mathrm{JM}-$ Acabou?

P - Sim, acabou. Como lhe disse, não conheço ainda o final dessa história.

JM - Em todo caso, pelo que você me contou, há uma diferença fundamental entre a sua odisseia e a Odisseia de Homero: Ulisses não consegue voltar para casa. Ulisses, na sua peça, não está desaparecido. Ele é um desaparecido.

P - Sim, a volta de Ulisses em carne e osso me parece uma impossibilidade nesse nosso mundo sem deuses. Aí acho que nem se trata propriamente de uma "atualização" no mau sentido, mas sim da tentativa de propor uma releitura fiel de Homero guiada por uma fidelidade ainda mais fundamental: uma fidelidade à nossa própria situação histórica.

JM - Sem dúvida. Acho que, pelo menos no plano do enredo, você não precisa ficar com medo de estar propondo uma atualização vulgarizante, por assim dizer. Em alguma medida, a distância histórica que nos separa do Ulisses de Homero não é menor do que a que nos separa desse Ulisses anônimo desaparecido na ditadura. Mas você não tem nenhuma ideia do que vai acontecer nessa confrontação do Telêmaco com o torturador?

P - Na verdade, pensei em alguns desfechos para a peça. Até agora, nenhum me satisfez. Um final condizente com o final da Odisseia, por exemplo, seria ele de fato matar o torturador. Talvez mesmo com requintes de crueldade. Mas, dada a situação objetiva dos ex-torturados, essa saída, sem dúvida catártica, faltaria à verdade histórica.

JM - Certamente faltaria. Só não sei se falaria em ex-torturados. Talvez falar em sobreviventes, em alusão ao livro do Primo Levi, soe melhor.

P - Você tem razão. Mas, como eu dizia, o meu medo de um desfecho catártico desse tipo tem a ver com um problema ético. Se, no mundo da cena, eu apresentasse como possível essa justiça arcaica, a justiça das Fúrias, talvez isso representasse uma espécie de acusação aos sobreviventes. Afinal, mesmo que indiretamente, uma vez que se aventa essa possibilidade objetiva, eles acabariam condenados como covardes que nem ao menos souberam se vingar.

JM - De fato, é preciso pensar em um outro desfecho possível. Aí se coloca de forma bastante crua o problema da justiça e da possível, ou impossível, reparação.

P - Querida Atena, você não tem nenhuma ideia?

JM - Agora, depois de tantas caipirinhas, fica difícil. Mas vamos especular: e se, depois de encontrar o torturador da mãe, Telêmaco não o matar? Ele é que hesitaria na hora fatal ou algum acontecimento simplesmente o impediria?

P - Não sei. Em todo caso, a lógica do perdão não me agrada. Talvez a lógica da impotência - o reconhecimento de que objetivamente não é possível matar um extorturador, se é que isso existe - seja mais interessante.

JM - No plano do enredo, o modo como você vai superar essa dúvida será fundamental para o posicionamento político da peça. Mas, no plano da construção do texto, me ocorre 
uma outra questão: com os atores simplesmente encarnando esses personagens que você imaginou, você não acha que fica difícil produzir as interrupções que, há pouco, julgávamos tão essenciais? A peça toda não tenderá a ficar dramática demais? Ou, na pior das hipóteses, melodramática?

$\mathrm{P}$ - De fato, esse é um risco. Mas é um risco que estou disposto a correr. Entre o dramalhão político e os insuportáveis jogos de cena característicos de um certo teatro contemporâneo, fico com o dramalhão. Mas não acho que esteja condenado a ele. Há uma delicadeza na descrição das cenas de tortura, por exemplo, que a direção pode encontrar.

JM - Acho que apresentá-las diretamente em cena não seria adequado. É preciso resguardar o que há de irrepresentável na representação.

$\mathrm{P}$ - Sem dúvida. Com relação a esse problema, pensei em usar inclusive um depoimento verídico que uma antiga militante deu à Comissão da Verdade. A atriz que fará a Penélope diria esse texto de maneira absolutamente neutra, sem demonstrar qualquer emoção.

JM - A princípio, gosto bastante dessa ideia.

P - Já com relação ao problema da interrupção do drama e da indispensável quebra da quarta parede, tive uma ideia que ainda preciso amadurecer. Pensei que o ator que fará o torturador deverá fazer também uma espécie de apresentador de telejornal, um William Bonner da vida, desses que têm o poder de forjar a realidade. Assim, na cena do confronto com o Telêmaco, sem qualquer justificativa realista, ele simplesmente escaparia de sua presença e reapareceria sentado diante de uma câmera da TV, apresentando as notícias do dia. Nesse contexto, qualquer elogio da lei e da ordem, qualquer condenação das ações dos "vândalos", por exemplo, ganharia um outro sentido.

JM - Olha, já está muito tarde e o Marcos acabou de mandar um recado dizendo que está me esperando na porta. Fiquei muito curiosa para ler essa tua peça. E, se tudo der certo, espero também poder vê-la no palco.

P - Pode deixar que, assim que estiver pronta, te mando, para saber das tuas impressões. Mesmo que repudie o cargo oficial de "consultora teórica", minha Atena continua sendo você.

JM - Ah, você é um Schmeichler [bajulador] incorrigível, como diriam os alemães.

$\mathrm{P}$ - Ainda bem que não sei o que é isso. Deve ser xingamento. Mas mande o meu abraço para o Marcos. Uma das coisas mais lindas que já li num livro de filosofia foi a dedicatória de um texto teu para ele, em que você dizia: "Ao Marcos, que nunca abriu mão da totalidade." Que inveja!

JM - Até a próxima visita. Tomara que vocês não tenham que se mudar dessa casa maravilhosa. E, assim que estiver pronto, me mande sim o texto da peça, não se esqueça.

Abstract: Our text presents a possible dialogue between $\mathrm{P}$, a playwright presently working on a theatrical adaptation of Homer's Odyssey, and JM, a philosopher that wrote some important studies on the dialectic of enlightenment

Cadernos Benjaminianos, Número especial, Belo Horizonte, 2013, página 26-40 
in the work of Homer. They investigate together how it would be possible to translate the Odyssey into the language of contemporary theatre without sacrificing the power embedded in its historical distance. At the end of the dialogue, $\mathrm{P}$ reads to JM the synopsis of his own odyssey to come.

Key-words: Benjamin, Brecht, Adorno, Homer

\section{Referências}

A CHINESA. Direção: Jean-Luc Godard. França, Cor, 1967. Título original: La chinoise. ADORNO, Theodor W.; HORKHEIMER, Max. Dialética do esclarecimento: fragmentos filosóficos. Rio de Janeiro: Jorge Zahar, 1985.

ADORNO, Theodor W. Educação e emancipação. São Paulo: Paz e Terra, 2003.

ARISTÓTELES. Poética. São Paulo: Ars Poética, 1992.

BENJAMIN, Walter. Magia e técnica, arte e política: ensaios sobre literatura e história da cultura. Trad. Sérgio Paulo Rouanet, São Paulo: Brasiliense, 2002. - (Obras escolhidas; v. 1)

BENJAMIN, Walter. O conceito de crítica de arte no romantismo alemão. São Paulo: Iluminuras, 2002.

BENJAMIN, Walter. Ensaios reunidos: escritos sobre Goethe. São Paulo: Ed. 34; Duas cidades, 2009.

BRECHT, Bertolt. Estudos sobre teatro. Rio de Janeiro: Nova Fronteira, 1978.

BRECHT, Bertolt. Um homem é um homem. São Paulo: Paz e Terra, 1992.

CAMPOS, Haroldo de. Poemas de Konstantinos Kaváfis. São Paulo: Cosac Naify, 2012. FÉNELON. Les aventures de Télémaque. Paris: Gallimard, 1995.

GAGNEBIN, Jeanne Marie. Lembrar escrever esquecer. São Paulo: Ed. 34, 2006.

GAGNEBIN, Jeanne Marie. Políticas da estética: entrevista concedida por Jeanne Marie Gagnebin a Romero Freitas e Luciano Gatti. In: Artefilosofia, Ouro Preto, n. 6, abril 2009, p. 106-122.

HOMERO. Odisseia. Trad. Trajano Vieira. São Paulo: Ed. 34, 2011.

O DESPREZO. Direção: Jean-Luc Godard. França/Itália, Cor, 1963. Título original: Le mépris.

O ENIGMA DE KASPAR HAUSER. Direção: Werner Herzog. Alemanha, Cor, 1974. Título original: Jeder für sich und Gott gegen alle.

SHAKESPEARE, William. Hamlet. Rio de Janeiro: Nova Aguilar, 1994.

TCHÉKHOV, Anton. A gaivota. São Paulo: Cosac Naify, 2004. 